\title{
Plasma and tissue digoxin concentrations in patients undergoing cardiopulmonary bypass
}

\author{
S. G. Carruthers, J. Cleland, J. G. Kelly, S. M. Lyons, and D. G. McDevitt \\ From The Department of Therapeutics and Pharmacology, The Queen's University, Belfast, and The Cardiac \\ Surgical Unit, The Royal Victoria Hospital, Belfast
}

\begin{abstract}
Plasma, myocardial, and skeletal muscle digoxin concentrations were measured in 32 patients undergoing cardiopulmonary bypass who were on long-term treatment with digoxin. The patients were divided into 4 groups according to their daily digoxin dose and the interval between discontinuation of the drug and operation. Before bypass, the mean digoxin concentrations were $1.58 \mathrm{nmol} / \mathrm{l}(1.24 \mathrm{ng} / \mathrm{ml}$ ) in plasma, $65.2 \mathrm{nmol} / \mathrm{kg}$ (50.9 $\mathrm{ng} / \mathrm{g}$ ) in the atria, I2I.4 $\mathrm{nmol} / \mathrm{kg}(94.8 \mathrm{ng} / \mathrm{g})$ in II papillary muscles, and $16.6 \mathrm{nmol} / \mathrm{kg}(13.0 \mathrm{ng} / \mathrm{g})$ in skeletal muscle. Mean atrial digoxin concentrations were significantly lower than mean papillary muscle concentrations in II patients. Ratios of plasma to myocardial or skeletal muscle digoxin concentrations were very variable. Generally digoxin concentrations were higher in patients on the larger digoxin dose and with the shorter discontinuation time before surgery. These differences attained significance only with plasma digoxin concentrations. There was a slight fall in plasma digoxin concentration during cardiopulmonary bypass but no significant differences were observed between plasma, atrial, or skeletal muscle digoxin concentrations before and at the end of bypass. No clear relation was seen between plasma or atrial digoxin concentrations and postoperative cardiotoxicity. Stopping digoxin 48 hours before operation appeared to account for pre-or post-bypass plasma digoxin concentrations of less than $1.0 \mathrm{nmol} / \mathrm{l}(0.8 \mathrm{ng} / \mathrm{ml})$ in most of the instances encountered, whereas the 3 patients who developed pulsus bigeminus postoperatively had received $0.5 \mathrm{mg}$ digoxin only 24 hours before operation.
\end{abstract}

The recent introduction of methods enabling the estimation of plasma digoxin concentrations has contributed significantly to knowledge of the clinical pharmacology of this drug. Therapeutic and toxic ranges of plasma digoxin concentrations have been identified in patients on chronic maintenance doses of dixogin (Smith, Butler, and Haber, 1969; Smith and Haber, 1970; Chamberlain et al., 1970; Evered and Chapman, 1971), though some overlap occurs between the two groups. A surprisingly large proportion of patients admitted to hospital appears to be taking inadequate amounts of digoxin (Carruthers, Kelly, and McDevitt, I974). Interpretation of plasma digoxin concentrations depends upon the assumption that a relatively constant relation exists between plasma and myocardial receptor site concentrations, since it is the latter (together with the response of the tissue) which ultimately determines the effect of the drug (Smith and Haber, 1972).

The relation between plasma and myocardial tissue digoxin concentrations has been the subject of a number of investigations. Initially Doherty, Received 22 July 1974 .
Perkins, and Flanigan (1967) suggested that a relatively constant ratio existed between the two, but subsequent investigations have not supported this (Binnion et al., 1969; Coltart, Howard, and Chamberlain, 1972; Carroll et al., 1973) and wide variations in myocardial tissue digoxin concentrations have been reported. Carroll et al. (1973) have recently suggested that there is no difference between the atrial and ventricular concentrations of the drug in humans, but this is at variance with results obtained from dogs (Deutscher, Harrison, and Goldman, 1972) and from human necropsy studies after administering radioactive digitoxin (Okita et al., 1955).

The effects of cardiopulmonary bypass on plasma and tissue digoxin levels have also been in dispute. A decrease in myocardial digoxin concentration, accompanied by a rise in plasma digoxin levels, has been reported as a result of bypass in both dogs (Austen et al., 1962) and humans (Ebert, Morrow, and Austen, 1963). Other authors have found, both in animals and man, that there is a significant drop in the plasma digoxin level which is not accom- 
panied by a corresponding change in myocardial concentration (Molokhia et al., 1971; Beall et al., 1963). However, the influence of bypass on skeletal muscle digoxin concentration has not been studied, despite the recognition that the storage capacity of this tissue for digoxin is enormous compared to the relatively small quantities of digoxin in plasma, heart, or other tissues (Doherty et al., 1967).

The present study was designed to determine and compare the cardiac, skeletal muscle, and plasma concentrations of digoxin in patients on two chronic dosage regimens, who had their digoxin discontinued at one of two preoperative intervals, and to examine the effects of cardiopulmonary bypass on the digoxin concentrations in these patients.

\section{Patients and methods}

Patients admitted for heart surgery under cardiopulmonary bypass were selected on the basis of their usual daily digoxin therapy. Sixteen patients had taken $0.25 \mathrm{mg}$ daily regularly and another 16 patients had taken $0.5 \mathrm{mg}$ daily. In each dosage group, 8 patients $(50 \%)$ were given their last preoperative dose of digoxin (Lanoxin, Burroughs Wellcome) 48 hours before surgery while the remainder received their final preoperative dose 24 hours later. Eight male and 24 female patients were studied. Their ages ranged from 30 to 68 years (mean 47 years). Routine investigations on the preoperative day included serum creatinine, plasma urea, and electrolyte estimation and a 12-lead electrocardiogram.

The operations were performed using conventional bypass techniques with a Rygg-Kyvsgaard ${ }^{1}$ bubble oxygenator and Sarns ${ }^{2}$ roller pump. The arterial flow was $2.4 \mathrm{l} / \mathrm{m}^{2}$ body surface area. The oxygenator was primed with 30 to $40 \mathrm{ml} / \mathrm{kg}$ of fluid composed of equal amounts of Hartmann's solution and 5 per cent dextrose in water. A further 10 to $15 \mathrm{ml} / \mathrm{kg}$ of 5 per cent dextrose in water was infused intravenously during the operation. Fluid composed of equal amounts of blood and Hartmann's solution was added to the oxygenator to maintain its level. Patients received on average I litre of blood in theatre.

Samples of blood, right atrial appendage, and pectoralis muscle from the edge of the sternotomy incision were taken just before bypass began. Depending on the duration of bypass, blood samples were taken at 10, 30, 90 , and 150 minutes. In addition, samples of papillary muscle were obtained from II patients. Further blood, right atrial appendage, and pectoralis muscle samples were taken at the end of bypass, and the duration of extracorporeal circulation was noted.

Carefully prepared fat-free samples of skeletal and cardiac muscle $(30-70 \mathrm{mg})$ were accurately weighed after lightly blotting dry. Digoxin was extracted by homogenizing with $2.5 \mathrm{ml}$ chloroform (Analar grade) on 2 separate occasions and removing the supernatants. The

${ }^{1}$ Rygg Kyvsgaard disposable bubble oxygenator (Polystan, Copenhagen).

${ }^{2}$ Sarns Inc., 6200 Jackson Road, Ann Arbor, Mich., U.S.A.

TABLE I Summary of observations in 32 chronically digitalized patients undergoing cardiopulmonary bypass. Results are expressed as mean \pm standard deviation. The figures in parentheses indicate the range of results.

\begin{tabular}{|c|c|c|c|c|c|c|c|c|}
\hline Group & $\begin{array}{l}\text { Daily } \\
\text { digoxin } \\
\text { dose }(m g)\end{array}$ & $\begin{array}{l}\text { Pro-op } \\
\text { interval } \\
\text { without } \\
\text { digoxin } \\
\text { (hr) }\end{array}$ & $\begin{array}{l}\text { No. of } \\
\text { patients }\end{array}$ & Sex & $\begin{array}{l}\text { Age } \\
(y r)\end{array}$ & $\begin{array}{l}K^{+} \\
(\mathrm{mmol} / \mathrm{l})\end{array}$ & $\begin{array}{l}\text { Urea } \\
\text { (mmolll) }\end{array}$ & $\begin{array}{l}\text { Creatinine } \\
(\mu \text { mol } / l)\end{array}$ \\
\hline A & 0.25 & 24 & 8 & $\begin{array}{l}M 2 \\
\text { F } 6\end{array}$ & $\begin{array}{c}47 \pm 19 \\
(34-63)\end{array}$ & $\begin{array}{c}4.6 \pm 0.8 \\
(3.7-5.6)\end{array}$ & $\begin{array}{c}6 \cdot 142 \pm 0.830 \\
(5 \cdot 312-6 \cdot 972)\end{array}$ & $\begin{array}{c}97.2 \pm 26.5 \\
(70.7-114.9)\end{array}$ \\
\hline B & 0.25 & 48 & 8 & $\begin{array}{l}\text { M } 3 \\
\text { F } 5\end{array}$ & $\begin{array}{c}52 \pm 8 \\
(42-68)\end{array}$ & $\begin{array}{c}4.2 \pm 0.3 \\
(3.8-4.7)\end{array}$ & $\begin{array}{c}6 \cdot 806 \pm 2 \cdot 158 \\
(4 \cdot 150-9 \cdot 794)\end{array}$ & $\begin{array}{c}88.4 \pm 26.5 \\
(70.7-123.8)\end{array}$ \\
\hline C & 0.5 & 24 & 8 & $\begin{array}{l}\text { M } 2 \\
\text { F } 6\end{array}$ & $\begin{array}{c}47 \pm 8 \\
(38-56)\end{array}$ & $\begin{array}{r}4.2 \pm 0.5 \\
(3.3-5.0)\end{array}$ & $\begin{array}{c}5 \cdot 644 \pm r \cdot 826 \\
(2 \cdot 656-8 \cdot 466)\end{array}$ & $\begin{array}{l}106.1 \pm 44.2 \\
(70.7-159.1)\end{array}$ \\
\hline D & 0.5 & 48 & 8 & $\begin{array}{l}\text { M I } \\
\text { F } 7\end{array}$ & $\begin{array}{c}43 \pm \text { I I } \\
(30-59)\end{array}$ & $\begin{array}{c}4.1 \pm 0.3 \\
(3.4-4.6)\end{array}$ & $\begin{array}{c}5 \cdot 312 \pm 1 \cdot 826 \\
(2 \cdot 324-7 \cdot 968)\end{array}$ & $\begin{array}{c}79.6 \pm 26.5 \\
(70.7-106.1)\end{array}$ \\
\hline
\end{tabular}

* $A F=$ atrial fibrillation; $S R=$ sinus rhythm.

† AVR, MVR, PVR, TVR indicate aortic, mitral, pulmonary, tricuspid valve replacement, respectively.

SI Units to Traditional Units:

Conversion factor- $\mathrm{K}^{+} \mathrm{I} \mathrm{mmol} / \mathrm{l}=\mathrm{I} \mathrm{mEq} / \mathrm{l}$; Urea $\mathrm{I} \mathrm{mmol} / 1 \approx 6 \mathrm{mg} / \mathrm{dl}$; Creatinine $\mathrm{I} \mu \mathrm{mol} / 1 \approx \mathrm{I} \cdot \mathrm{I} 3 \mathrm{mg} / \mathrm{dl}$. 
supernatant from a third extraction showed no evidence of digoxin. The first 2 supernatants were mixed and aliquots used for digoxin determination. The digoxin content of plasma and tissue extracts was measured by the radioimmunoassay method of Smith et al. (1969) using the Wellcome $\beta$-Lanoxitest kit modified according to Ojala, Karjalainen, and Reissell (1972). Tissue concentrations of digoxin were subsequently calculated from knowledge of tissue weights and the amounts of digoxin detected in the supernatants.

Statistical analyses were carried out using Student's t test. Differences were considered significant when the probability $(\mathrm{P})$ was less than 0.05 . All results are expressed as the mean \pm standard deviation.

\section{Results}

Observations on sex, age, electrocardiographic and biochemical data, operation, and duration of cardiopulmonary bypass are shown in Table I for each of the 4 groups of 8 patients, divided according to daily digoxin dosage and drug discontinuation time.

One patient underwent repair of an atrial septal defect and had an aortic homograft valve replacement of the pulmonary valve for a congenital defect, but all other valve replacements were of the StarrEdwards ball valve type. There was a fivefold variation in the duration of bypass in all subjects ( 45 to 210 minutes) and a twofold variation in the mean between groups (69 to 120 minutes). The mean

\begin{tabular}{|c|c|c|}
\hline$E C G^{\star}$ & Operation† & $\begin{array}{l}\text { Duration } \\
\text { of bypass } \\
\text { (min) }\end{array}$ \\
\hline $\begin{array}{l}5 \mathrm{AF} \\
3 \mathrm{SR}\end{array}$ & $\begin{array}{l}\text { I AVR } \\
4 \text { MVR } \\
\text { I AVR, MVR } \\
\text { I AVR, MVR, TVR } \\
\text { I PVR, repair, ASD }\end{array}$ & $\begin{array}{l}120 \pm 53 \\
(47-216)\end{array}$ \\
\hline $\begin{array}{l}7 \mathrm{AF} \\
\text { I SR }\end{array}$ & $\begin{array}{l}\text { I AVR } \\
6 \text { MVR } \\
\text { I Mitral valvotomy }\end{array}$ & $\begin{array}{l}80 \pm 48 \\
(45-199)\end{array}$ \\
\hline $\begin{array}{l}6 \mathrm{AF} \\
2 \mathrm{SR}\end{array}$ & $\begin{array}{l}2 \text { MVR } \\
5 \text { AVR, MVR } \\
\text { I MVR, TVR }\end{array}$ & $\begin{array}{l}\text { I } 10 \pm 48 \\
(50-210)\end{array}$ \\
\hline $\begin{array}{l}6 \mathrm{AF} \\
2 \mathrm{SR}\end{array}$ & $\begin{array}{l}\text { I AVR } \\
5 \text { MVR } \\
\text { I AVR, MVR } \\
\text { I MVR, TVR }\end{array}$ & $\begin{array}{c}69 \pm 29 \\
(51-140)\end{array}$ \\
\hline
\end{tabular}


TABLE 2 Plasma, atrial, and skeletal muscle digoxin concentrations at the beginning and end of cardiopulmonary bypass. Mean $\pm S D$ in each of 4 groups of 8 subjects

\begin{tabular}{|c|c|c|c|c|c|c|}
\hline \multirow{2}{*}{ Group } & \multicolumn{3}{|c|}{ Pre-bypass digoxin concentrations } & \multicolumn{3}{|c|}{ Post-bypass digoxin concentrations } \\
\hline & $\begin{array}{l}\text { Plasma } \\
\text { (nmol/l) }\end{array}$ & $\underset{(\text { nmol } / k g)}{\text { Atrium }}$ & $\begin{array}{c}\text { Skeletal } \\
\text { muscle } \\
(\text { nmol/kg) }\end{array}$ & $\begin{array}{r}\text { Plasma } \\
\text { (nmol/l) }\end{array}$ & $\underset{(\text { nmol } / k g)}{\text { Atrium }}$ & $\begin{array}{c}\text { Skeletal } \\
\text { muscle } \\
\text { (nmol/kg) }\end{array}$ \\
\hline $\begin{array}{l}\text { A } \\
\text { B } \\
\text { C } \\
\text { D }\end{array}$ & $\begin{array}{l}1.8 \pm 0.6 \\
1.2 \pm 0.4 \\
2.2 \pm 0.9 \\
1.2 \pm 0.6\end{array}$ & $\begin{array}{l}61.4 \pm 32.5 \\
50.0 \pm 23.4 \\
84.5 \pm 20.9 \\
64.9 \pm 41.9\end{array}$ & $\begin{array}{l}17.2+8.4 \\
12.7 \pm 8.4 \\
22.5 \pm 15.2 \\
14.3 \pm 10.9\end{array}$ & $\begin{array}{l}1.7 \pm 0.6 \\
0.9 \pm 0.4 \\
2.4 \pm 1.0 \\
1.0 \pm 0.5\end{array}$ & $\begin{array}{l}60.9 \pm 36.6 \\
54.9 \pm 25.1 \\
84.7 \pm 21.6 \\
55.5 \pm 54.5\end{array}$ & $\begin{array}{l}13.9 \pm 10.9 \\
11.1 \pm 6.1 \\
20.7 \pm 14.6 \\
13.7 \pm 7.8\end{array}$ \\
\hline All groups & $1.5 \pm 4.6$ & $65.2 \pm 185.3$ & $16.6 \pm 65.2$ & $1.5 \pm 4.7$ & $64.0 \pm 203.1$ & $14.9 \pm 59.9$ \\
\hline
\end{tabular}

SI Units to Traditional Units: Conversion factor-Digoxin I nmol $/ 1 \approx 0.78 \mathrm{ng} / \mathrm{ml} ; \mathrm{I} \mathrm{nmol} / \mathrm{kg} \approx 0.78 \mathrm{ng} / \mathrm{mg}$

even though 2 patients had atrial concentrations just greater than papillary concentrations.

Assuming an elimination half-life for digoxin of I.6 days (Jeliffe, 1968), near normal renal function, and that the studies in rats, using tritiated digoxin which showed that decay occurred in all tissues at the same rate (Okita, 1969) are indicative of human tissue response, it is possible to extrapolate the digoxin concentrations found in atrial and skeletal muscle at 24 and 48 hours back to zero-time. This would give mean atrial digoxin concentrations at zero-time of $108.2 \mathrm{nmol} / \mathrm{kg}(84.5 \mathrm{ng} / \mathrm{g})$ for patients taking $0.25 \mathrm{mg}$ daily and $142.4 \mathrm{nmol} / \mathrm{kg}$ (III.2 ng/g) for those taking $0.5 \mathrm{mg}$ daily. The comparable mean digoxin concentrations for skeletal muscle would be 28.3 and $34.4 \mathrm{nmol} / \mathrm{kg}(22.1 \mathrm{ng} / \mathrm{g}$ and $26.9 \mathrm{ng} / \mathrm{g})$ for the two dose levels, respectively.

\section{Effects of cardiopulmonary bypass}

The mean plasma digoxin levels in each group at the various times of sampling during cardiopulmonary bypass are shown in Table 3 . There is a decline in the mean plasma level with an observed minimum between 30 and 90 minutes and a return at the end of bypass to levels which approximate to those found initially. None of these changes reaches statistical significance. The overall mean plasma digoxin levels were $1.5 \mathrm{nmol} / 1(\mathrm{I} .2 \mathrm{ng} / \mathrm{ml}$ ) (before bypass), I.4 nmol/1 (I.I ng/ml) (IO $\mathrm{min}$ ), $1.4 \mathrm{nmol} / 1$ (I.I ng/ml) (30 $\mathrm{min}$ ), $1.7 \mathrm{nmol} / 1$ (1.3 ng/ml) (90 $\mathrm{min}$ : $\mathrm{n}=\mathrm{r} 4)$ and $\mathrm{r} .5 \mathrm{nmol} / 1$ ( $\mathrm{r} .2 \mathrm{ng} / \mathrm{ml}$ ) (end of bypass).

Mean plasma, atrial, and skeletal muscle digoxin levels within each group show no significant change after bypass (Table 2). The mean pre- and postbypass tissue levels are distinctly similar: $\mathrm{I} .5$ $\mathrm{nmol} / \mathrm{l}$ and $\mathrm{I} .5 \mathrm{nmol} / 1$ ( $\mathrm{r} .2 \mathrm{ng} / \mathrm{ml}$ and $1.2 \mathrm{ng} / \mathrm{ml}$ ) respectively for plasma, $65.2 \mathrm{nmol} / \mathrm{kg}(50.9 \mathrm{ng} / \mathrm{g}$ ) and $64.0 \mathrm{nmol} / \mathrm{kg}$ (50.0 ng/g), respectively, for atrial muscle and $16.6 \mathrm{nmol} / \mathrm{kg}$ and $15.0 \mathrm{nmol} / \mathrm{kg}$
(13.0 $\mathrm{ng} / \mathrm{g}$ and II.7 $\mathrm{ng} / \mathrm{g}$ ) for skeletal muscle digoxin concentrations. However, within individual patients there were many occasions when plasma and tissue digoxin levels rose or fell appreciably during the bypass procedure. There was a considerable degree of overlap between these patients and there was no clear evidence of any pattern in the changes observed.

\section{Postoperative clinical course}

Two patients did not achieve adequate cardiac output on termination of bypass and subsequently died in spite of supportive measures. Postoperative plasma digoxin levels in these patients were within the acceptable range at $\mathrm{I} .7$ and $1.8 \mathrm{nmol} / \mathrm{l}$ ( $\mathrm{I} .3$ and I.4 $\mathrm{ng} / \mathrm{ml}$ ), respectively. Their necropsy studies showed considerable myocardial ischaemia. Two patients, who had low preoperative plasma digoxin levels of 0.5 and $0.8 \mathrm{nmol} / 1(0.4$ and $0.6 \mathrm{ng} / \mathrm{ml}$ ), developed rapid atrial fibrillation within 6 to 8 hours of operation, which responded to further digoxin therapy. Three patients whose plasma digoxin levels at the end of bypass were $1.8,2.8$, and $4.1 \mathrm{nmol} / 1$ ( $\mathrm{I} .4,2.2$, and $3.2 \mathrm{ng} / \mathrm{ml}$ ), subsequently developed runs of pulsus bigeminus. However, 5 patients whose plasma digoxin levels had not been above $0.9 \mathrm{nmol} / 1(0.7 \mathrm{ng} / \mathrm{ml})$ and 2 patients with post-bypass plasma concentrations of 2.7 and $3.7 \mathrm{nmol} / 1$ (2.I and $2.9 \mathrm{ng} / \mathrm{ml})$ underwent their operations without any postoperative complications. Three patients died within I4 days of the study as a result of thromboembolic complications. This problem has been described elsewhere (Cleland and Molloy, 1973).

\section{Discussion}

The patients in this study had all been in heart failure and the majority suffered also from atrial 
TABLE 3 Plasma levels of digoxin (nmol/l) measured before, during and at the end of cardiopulmonary bypass (mean $\pm S D$ ). Values for 8 subjects except where stated. The mean duration of bypass was $95 \pm 45$ minutes

\begin{tabular}{|c|c|c|c|c|c|}
\hline Group & Before bypass & $10 \mathrm{~min}$ & $30 \mathrm{~min}$ & $90 \min$ & End of bypass \\
\hline $\mathbf{A}$ & $1.8 \pm 0.6$ & $1.8 \pm 1.2$ & $1.5 \pm 0.8$ & $\begin{array}{l}1.9 \pm 1.2 \\
(n=6)\end{array}$ & $1.7 \pm 0.6$ \\
\hline B & $1.2 \pm 0.4$ & $0.9 \pm 0.4$ & $0.9 \pm 0.4$ & $\begin{array}{l}1.5 \\
(n=1)\end{array}$ & $0.9 \pm 0.4$ \\
\hline C & $2.2 \pm 0.9$ & $1.9 \pm 1.0$ & $2.0 \pm 1.0$ & $\begin{array}{l}1.8 \pm 0.5 \\
(n=5)\end{array}$ & $2.4 \pm I .0$ \\
\hline D & $\mathrm{I} .2 \pm 0.6$ & $1.0 \pm 0.3$ & $0.9 \pm 0.3$ & $\begin{array}{l}0.8 \pm 0.1 \\
(n=2)\end{array}$ & $1.0 \pm 0.5$ \\
\hline All groups & $1.5 \pm 4.6$ & $1.4 \pm 5.2$ & $1.4 \pm 4.7$ & $1.7 \pm 3.5$ & $1.5 \pm 4.7$ \\
\hline
\end{tabular}

Conversion SI to Traditional Units: Digoxin I nmol/1 $\approx 0.78 \mathrm{ng} / \mathrm{ml}$.

fibrillation (Table I). Preoperatively, heart rate had been adequately controlled in all cases and clinical signs of heart failure removed by the use of digoxin with addition of a diuretic and potassium supplements in most cases.

The range of pre-bypass plasma digoxin concentrations in the present series is comparable to that reported from similar studies (Coltart et al., 1972; Carroll et al., 1973). However, direct comparisons between different series are difficult because of the variability in, or lack of information about, digoxin dosage regimens and intervals between discontinuation of therapy and sampling blood and tissue digoxin levels. Thus, some authors have neglected to state the usual daily dose and drug discontinuation interval before surgery (Coltart et al., 1972), others have stopped digoxin treatment at the same time in patients receiving different doses (Binnion et al., 1969) or have brought together patients with both different dosage regimens and different intervals between drug discontinuation and operation (Carroll et al., 1973). In these studies, the results were analysed in total groups. While such variations may not affect plasma/tissue digoxin concentration ratios, they will undoubtedly affect the values obtained for individual plasma and tissue digoxin concentrations as is shown in the present study by the results in Table 2.

The atrial digoxin levels in this study ranged from 2.9 to $166.7 \mathrm{nmol} / \mathrm{kg}(2.3$ to $130.2 \mathrm{ng} / \mathrm{g}$ ), with a mean of $65.2 \mathrm{nmol} / \mathrm{kg}(50.9 \mathrm{ng} / \mathrm{g})$. These results appear lower than those obtained by Carroll et al. (1973), but I6 of their 21 patients were taking digoxin, $0.5 \mathrm{mg}$ daily or greater, and it is not clear how many of these discontinued their therapy only 24 hours before operation. Similarly, higher mean atrial digoxin concentrations have been reported by Binnion et al. (1969) using a rubidium-86 red cell uptake method for analysis $280.4 \pm 53 \mathrm{nmol} / \mathrm{kg}$
(219 $\pm 42 \mathrm{ng} / \mathrm{g})$ and by Beall et al. (1963) 6 hours after I mg tritiated digoxin was given intravenously (I40 $\mathrm{ng} / \mathrm{g}$ ).

In I I patients, papillary muscle concentrations ranged from 29.6 to $202.7 \mathrm{nmol} / \mathrm{kg}$ (23.1 to 158.3 $\mathrm{ng} / \mathrm{g})$, with a mean of $121.4 \pm 53.1 \mathrm{nmol} / \mathrm{kg}(94.8 \pm$ $41.5 \mathrm{ng} / \mathrm{g}$ ). This group is undifferentiated for dosage and time interval because of the small numbers involved. It is similar to the range 19.8I69 $\mathrm{nmol} / \mathrm{kg}$ (15.5-132 $\mathrm{ng} / \mathrm{g}$ ) and mean $99.5 \pm$ $55.4 \mathrm{nmol} / \mathrm{kg}(77.7 \pm 43.3 \mathrm{ng} / \mathrm{g})$ reported for left ventricular papillary muscle digoxin concentrations in 8 patients by Coltart et al. (1972).

The similarity between the mean atrial digoxin concentration $97.9 \mathrm{nmol} / \mathrm{kg}(76.5 \mathrm{ng} / \mathrm{g})$ obtained by Carroll et al. (1973) and the mean left ventricular papillary muscle concentration reported by Coltart et al. (1972) led Carroll and his colleagues to postulate that there is no difference between atrial and ventricular concentration of the drug in patients on digoxin therapy. However, in our II patients, the mean digoxin level in papillary muscle was significantly greater than that in atrial muscle. This finding is in accord with atrioventricular digoxin concentration relations previously demonstrated in animals (Gruber, Luchi, and Turnbull, I967; Deutscher et al., 1972), in human necropsy material (Okita et al., 1955) and in the patients in this present study who came to necropsy (S. G. Carruthers, J. G. Kelly and D. G. McDevitt, unpublished observations). Why different parts of the myocardium should have distinctly different digoxin concentrations remains uncertain.

Skeletal muscle digoxin concentrations also show a gradient for different dosage levels and time intervals (Table 2). In this case, with the small numbers of patients within the groups, the differences did not attain significance. Extrapolation to zero-time gave mean skeletal muscle digrxin con- 
centrations of $28.3 \mathrm{nmol} / \mathrm{kg}(22.1 \mathrm{ng} / \mathrm{g}$ ) for patients taking $0.25 \mathrm{mg}$ and $34.4 \mathrm{nmol} / \mathrm{kg}(26.9 \mathrm{ng} / \mathrm{g})$ for a daily dose of $0.5 \mathrm{mg}$. Therefore, the possibility exists for differentials between mean skeletal muscle digoxin concentrations attained at different daily digoxin dosages. The ratio of atrial to skeletal muscle digoxin concentrations (about $4: I$ ) is in agreement with that described in dogs given tritiated digoxin intravenously (Deutscher et al., 1972).

In this present study the ratios of plasma digoxin concentrations to the concentrations found in other tissues showed a similar variability to that described by previous authors (Doherty et al., 1967; Binnion et al., 1969; Coltart et al., 1972; Carroll et al., 1973). The range of the ratios for atrial to plasma digoxin concentrations was 2.8:I to $124:$ I (mean 46.3:I), for skeletal muscle to plasma was I.9: I to 35.3:I (mean 13.2:1) and for papillary muscle to plasma digoxin 39.3: I to I $14.4:$ I (mean 70.6:I).

Reasons for the observed variability in ratios between plasma and myocardial digoxin have been reviewed by Coltart et al. (1972). They suggest that plasma digoxin concentrations may provide a more meaningful index of therapeutic activity than total myocardial concentrations as only about ro per cent of myocardial digoxin may be bound to active sites (Kuschinsky et al., 1967).

The effect of cardiopulmonary bypass on plasma digoxin concentrations was similar to that shown by Coltart et al. (197r). The plasma digoxin levels did not fall as low or remain low for as long as in Coltart's study, but the mean initial plasma digoxin concentration was lower and the mean duration of bypass shorter. A decline in plasma digoxin level was seen as soon as Io minutes after the institution of bypass and this supports the idea that it probably represents a dilution of the plasma volume by pump and intravenous infusion fluids.

In addition, our findings indicate that there is no appreciable loss of digoxin from the atrial tissue during cardiopulmonary bypass in patients on chronic maintenance digoxin therapy. This is in agreement with the recent study in 8 dogs by Molokhia et al. (1971) and the clinical observations of Beall et al. (1963). Previously, loss of myocardial digoxin during cardiopulmonary bypass had been reported both in animals (Austen et al., 1962) and in man (Ebert et al., 1963). It now appears, however, that evidence is accumulating for maintenance of digoxin concentration in myocardial tissue during bypass.

In the four groups of patients under study, the skeletal muscle digoxin concentrations fell on average by 0.6 to $3.2 \mathrm{nmol} / \mathrm{kg}$ ( 0.5 to $2.5 \mathrm{ng} / \mathrm{g}$ ) with an overall mean of $1.7 \mathrm{nmol} / \mathrm{kg}(\mathrm{I} .3 \mathrm{ng} / \mathrm{g})$. The differ- ence was not significant and may represent variarion in the technique or site of sample collection or the experimental error of the quantitation of the skeletal muscle digoxin content. However, if the difference were real and if the skeletal muscle mass amounts to even 40 per cent of body weight, in a $70 \mathrm{~kg}$ man a change of $1.7 \mathrm{nmol} / \mathrm{kg}(\mathrm{I} .3 \mathrm{ng} / \mathrm{g}$ ) in skeletal muscle digoxin concentration would provide $0.05 \mathrm{nmol}(0.036 \mathrm{mg}$ ) digoxin (or about oneseventh of a $0.25 \mathrm{mg}$ dose) for availability to plasma, myocardium, or other tissue. Coltart et al. (I972) showed that a mean total of $0.2 \mathrm{mmol}$ (0.134 mg) digoxin was lost from the urinary tract and a much smaller amount via the oxygenator and discard suction bottle during bypass over an average of 8 hours in I I patients on maintenance digoxin therapy. They felt that this amount was comparable to the normal urinary digoxin excretion in these people under normal circumstances, but if there were an actual loss of digoxin during bypass, this present study would suggest that restoration of plasma and myocardial digoxin levels could occur with only trivial changes in skeletal muscle digoxin concentrations.

Despite the wide variations between subjects in the levels of digoxin found in the various tissues, there must be a fairly stable relation within each individual as a mere I per cent shift of digoxin from skeletal muscle to plasma would produce a 100 per cent increase in plasma digoxin concentration, and a 5 per cent transfer from skeletal muscle to the myocardium would double the cardiac level. Such changes in plasma and cardiac digoxin concentration could be of great importance, yet the changes in skeletal muscle digoxin would be difficult to measure.

The patient undergoing cardiopulmonary bypass appears to be at particular risk if his digoxin dosage is inadequate or excessive. Lack of digitalis predisposes to poor inotropic action at a time when the myocardium has suffered the mechanical injury of surgery, and the poor pump performance may be aggravated by inadequately controlled atrial fibrillation. Metabolic changes may increase myocardial irritability (Pacifico, Digerness, and Kirklin, 1970) thereby accentuating the dangerous arrhythmias of digoxin toxicity. Plasma digoxin concentrations from $1.0-2.6 \mathrm{nmol} / 1(0.8-2.0 \mathrm{ng} / \mathrm{ml})$ have been described as being within "the observed "normal" therapeutic range' (Whiting, Sumner, and Goldberg, 1973) for patients with normal renal function on standard daily digoxin dosage. In addition, plasma digoxin levels of $2.6 \mathrm{nmol} / 1(2.0 \mathrm{ng} / \mathrm{ml})$ or greater demand caution as they are often associated with impending or actual digoxin toxicity.

In the present study, approximately two-thirds of the patients had satisfactory pre-bypass plasma 
digoxin levels - consistent with their normal or near normal renal function and relatively young average age group. Five patients had levels greater than $2.6 \mathrm{nmol} / 1(2.0 \mathrm{ng} / \mathrm{ml})$ before bypass and of these two developed cardiac arrhythmias after surgery; 2 patients developed rapid atrial fibrillation within 6 to 8 hours of operation which responded to further digoxin and both of these came from the group of 7 patients who had pre-bypass plasma digoxin concentrations less than $1.0 \mathrm{nmol} / 1$ ( 0.8 $\mathrm{ng} / \mathrm{ml}$ ). The relation of atrial digoxin concentrations to cardiotoxicity is not clear. Carroll et al. (1973) noted serious postoperative complications in 3 of 4 patients with right atrial myocardial concentrations greater than $128 \mathrm{nmol} / \mathrm{kg}$ (100 $\mathrm{ng} / \mathrm{g}$ ) but in only 2 of 23 patients with concentrations less than 128 $\mathrm{nmol} / \mathrm{kg}$ (100 ng/g). However, in the present study the 3 patients who had runs of bigeminus had atrial digoxin concentrations of 85.4, II 2.0 , and 94 $\mathrm{nmol} / \mathrm{kg}(66.7,87.5$, and $73.7 \mathrm{ng} / \mathrm{g})$, respectively, but no arrhythmia occurred in Io other patients with post-bypass atrial concentrations ranging from 76.8 to $170.3 \mathrm{nmol} / \mathrm{kg}$ ( 60 to $133 \mathrm{ng} / \mathrm{g}$ ). Hence knowledge of atrial digoxin concentration does not appear to be of value in the prediction of postbypass arrhythmias.

The 5 patients whose postoperative complications might definitely be associated with inadequate (2) or excessive digoxin administration (3) had all been on $0.5 \mathrm{mg}$ digoxin daily. The 2 patients who developed fast atrial fibrillation had stopped treatment 48 hours before operation, while the 3 patients who developed pulsus bigeminus had received their last $0.5 \mathrm{mg}$ dose only 24 hours before operation. The group of patients on $0.25 \mathrm{mg}$ daily who stopped treatment for 48 hours before operation included 5 (out of a total of 8 ) whose post-bypass plasma levels were less than $1.0 \mathrm{nmol} / 1(0.8 \mathrm{ng} / \mathrm{ml})$, though no evidence of inadequate digoxin treatment developed.

We should like to thank Mr. P. J. Molloy for the supply of some tissue samples, Drs. R. S. J. Clarke and J. D. Morrison for assistance in collecting them, and Dr. G. R. Wilkinson for helpful discussion. Mr. W. Leahey and Miss G. McClean provided valuable technical assistance.

\section{References}

Austen, W. G., Ebert, P. A., Greenfield, L. J., and Morrow, A. G. (1962). The effect of cardiopulmonary bypass on tissue digoxin concentrations in the dog. Fournal of Surgical Research, 2, 85 .

Beall, A. C., Johnson, P. C., Driscoll, T., Alexander, J. K., Dennis, E. W., McNamara, D. G., Cooley, D. A., and DeBakey, M. E. (1963). Fffect of total cardiopulmonary bypass on myocardial and blood digoxin concentration in man. American fournal of Cardiology, $11,194$.

Binnion, P. F., Morgan, L. M., Stevenson, H. M., and Fletcher, E. (1969). Plasma and myocardial digoxin con- centrations in patients on oral therapy. British Heart fournal, 31, 636.

Carroll, P. R., Gelbart, A., O'Rourke, M. F., and Shortus, J. (1973). Digoxin concentrations in the serum and myocardium of digitalised patients. Australian and New Zealand Fournal of Medicine, 3, 400.

Carruthers, S. G., Kelly, J. G., and McDevitt, D. G. (1974). Plasma digoxin concentrations in patients on admission to hospital. British Heart fournal, 36, 707.

Chamberlain, D. A., White, R. J., Howard, M. R., and Smith, T. W. (1970). Plasma digoxin concentration in patients with atrial fibrillation. British Medical fournal, 3, 429.

Cleland, J., and Molloy, P. J. (1973). Thrombo-embolic complications of the cloth-covered Starr-Edwards prosthesis No. 2300 aortic and No. 6300 mitral. Thorax, 28, 4 I.

Coltart, D. J., Chamberlain, D. A., Howard, M. R., Kettlewell, M. G., Mercer, J. L., and Smith, T. W. (I97I). Effect of cardiopulmonary bypass on plasma digoxin concentrations. British Heart fournal, 33, 334.

Coltart, D. J., Howard, M. R., and Chamberlain, D. A. (1972). Myocardial and skeletal muscle concentrations of digoxin in patients on long-term therapy. British Medical fournal, $2,318$.

Deutscher, R. N., Harrison, D. C., and Goldman, R. H. (1972). The relationship between myocardial $3 \mathrm{H}$-digoxin concentration and its hemodynamic effects. American fournal of Cardiology, 29, 47.

Doherty, J. E., Perkins, W. H., and Flanigan, W. J. (I967). The distribution and concentration of tritiated digoxin in human tissues. Annals of Internal Medicine, 66, I 16.

Ebert, P. A., Morrow, A. G., and Austen, W. G. (1963). Clinical studies of the effect of extracorporeal circulation on myocardial digoxin concentration. American fournal of Cardiology', II, 201.

Evered, D. C., and Chapman, C. (1971). Plasma digoxin concentrations and digoxin toxicity in hospital patients. British Heart fournal, 33, 540.

Evered, D. C., Chapman, C., and Hayter, C. J. (1970). Measurement of plasma digoxin concentration by radioimmunoassay. British Medical fournal, 3, 427.

Gruber, J. W., Luchi, R. J., and Turnbull, J. S. (1967). Cardiac distribution of $\mathrm{H}^{3}$-digoxin and its alteration by reserpine. Circulation, 36, Suppl. 2, 127.

Jeliffe, R. W. (1968). An improved method of digoxin therapy. Annals of Internal Medicine, 69, 703.

Kuschinsky, K., Lahrtz, H., Lüllman, H., and Van Zwieten, P. A. (1967). Accumulation and release of ${ }^{3} \mathrm{H}$-digoxin by guinea-pig heart muscle. British fournal of Pharmacology and Chemotherapy, 30, 317.

Molokhia, F. A., Beller, G. A., Smith, T. W., Asimacopoulos, P. J., Hood, W. B., and Norman, J. C. (I97I). Constancy of myocardial digoxin concentration during experimental cardiopulmonary bypass. Annals of Thoracic Surgery, II, 222.

Ojala, K., Karjalainen, J., and Reissell, P. (I972). Radioimmunoassay of digoxin. Lancet, I, I 50.

Okita, G. T. (1969). Distribution, disposition, and excretion of digitalis glycosides. In Digitalis, pp. 13-26. Ed. by C. Fisch and B. Surawicz. Grune and Stratton, New York.

Okita, G. T., Talso, P. J., Curry, J. H., Smith, F. D., Jr., and Geiling, E. M. K. (1955). Metabolic fate of radioactive digitoxin in human subjects. Fournal of Pharmacology and Experimental Therapeutics, 115,371 .

Pacifico, A. D., Digerness, S., and Kirklin, J. W. (1970). Acute alterations of body composition after open intracardiac operations. Circulation, 4I, 33I.

Smith, T. W., Butler, V. P., and Haber, E. (1969). Determination of therapeutic and toxic serum digoxin concentratrations by radioimmunoassay. New England fournal of Medicine, 281, I 212. 
Smith, T. W., and Haber, E. (1970). Digoxin intoxication: the relationship of clinical presentation to serum digoxin concentration. fournal of Clinical Investigation, 49, 2377.

Smith, T. W., and Haber, E. (1972). Clinical application of the determination of digitalis blood levels. In Basic and Clinical Pharmacology of Digitalis, p. 294. Ed. by B. H. Marks and A. M. Weissler. Charles C. Thomas, Springfield, Illinois.
Whiting, B., Sumner, D. J., and Goldberg, A. (1973). An assessment of digoxin radioimmunoassay. Scottish Medical fournal, 18, 69.

Requests for reprints to Dr. S. G. Carruthers, Department of Therapeutics and Pharmacology, The Institute of Clinical Science, Grosvenor Road, Belfast BTI2 6BJ, Northern Ireland. 